\title{
Counselor Librarianship at U.I.C.
}

(Continued from page I66)

so that both library knowledge and library skills-before as well as after library instruction-can be more effectively studied in relation to the general institutional program and in relation to all library activities.

(5) It is intended that, when the projected series of divisional reading rooms at last comes into being, advanced library instruction will be considered for certain subject fields. The present Fine Arts Librarian, however, has opportunities even now to discuss fine arts library materials and bibliographic techniques at occasional sessions of architecture and art classes.

(6) When graduate curricula are finally added to the U.I.C., suitable expansions of the present Department of Library Instruction and Advisement can be readily made. Specialized reference librarians, research bibliographers, etc., can be added without difficulty, and without disorganizing the undergraduate program. (It should be emphasized that the current research and development needs of the present U.I.C. faculty are in no way being slighted.)

\section{CONCLUSION}

In 1952, a well-known library author stated that the college librarian can "also be a valued member of the guidance and counseling staff" of the institution to which he belongs. This authority, however, did not go on to outline any specific arrange- ments whereby a college library could participate effectively in a fully developed counseling and advisement program. ${ }^{13}$ The U.I.C.'s Department of Library Instruction and Advisement, set up in I95I, provides definite machinery whereby librarians become recognized members of the local counseling staff. Since many other institutions, including high schools, junior colleges, four-year colleges, and universities have similar student personnel programs, Counselor Librarianship of the U.I.C. type possibly could be considered elsewhere. Public librarians, special librarians, library associations, and library schools also could consider using selected viewpoints and experience from the fields of counseling, personnel work, and applied psychology. Reader-service programs of all kinds might benefit significantly from such "cross fertilization."**

13 See Chapter XV entitled The Library: An Opportunity in: Johnson, B. L., General Education in Action (Washington, D.C., American Council on Education, I952) p. 328-34I." A shortened version appears in College and Research Libraries I3: I 26-130, April I952. (It is perhaps unfortunate that Johnson aimed this article specifically at the junior college library, since article specifically at the junior college library, since library.)

* For a more detailed treatment of the U.I.C. program with extensive discussion of counseling procedures, see Mr. Maxfield's Counselor Librarianship: $A$ Nere Departure, which is Occasional Paper, No. 38 (March 1054) of the University of Illinois Library School. Free copies are available to those who write to Urbana, Illinois.

\section{Seventh Edition Supplement}

ALA has announced the publication of Guide to Reference Books: 7th Edition Supplement 1950-1952, by Constance M. Winchell and Olive A. Johnson. (Chicago, ALA, I954. I40p.)

This supplement describes approximately ıoo useful reference works in all fields, published between 1950 and June 1953. It includes, in addition, a few earlier titles omitted from the 7 th edition. The Supplement brings up-to-date the indispensable Guide to Reference Books, a basic work for scholars, reference workers, and library school students. While this work is proudly issued by ALA, it might be said to add to the bicentennial laurels of Columbia University.

Miss Winchell's semi-annual series on "Selected Reference Books" appears regularly in the January and July issues of $C \varepsilon^{\circ} R L$. 